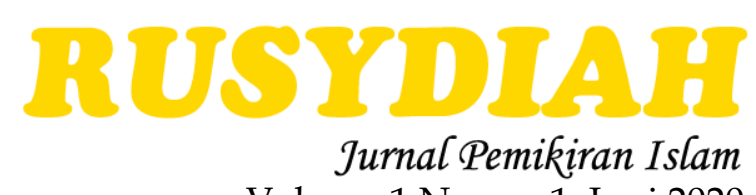

Volume 1 Nomor 1, Juni 2020

ISSN: 2723-4894 (cetak), ISSN: 2723-4886 (daring)

DOI: https://doi.org/10.35961/rsd.v1i1.125

\title{
POLIGAMI MENURUT KITAB TAFSIR AL-MA'RIFAH KARYA MUSTHAFA UMAR
}

\author{
M. Kafrawi \\ STAIN Sultan Abddurahman Kepulauan Riau \\ m.kafrawi@stainkepri.ac.id \\ Mohd Nazri Ahmad \\ Universiti Kebangsaan Malaysia \\ m_nazri@ukm.edu.my
}

\begin{abstract}
Abstrak
Artikel ini membahas tentang poligami menurut sudut pandang kitab Tafsir al-Ma'rifah karangan Musthafa Umar dengan menggunakan metode analisa deskriptif dan teori Islahi I'jtima'i. Dalam penelitian ini, penulis menemukan bahwa kitab Tafsir al-Ma'rifah ini membahas poligami dari aspek perbaikan masyarakat (Islah Ijtima'i). Dari segi asbabun nuzul, kitab ini hanya menggambarkan secara umum sejarah turunnya ayat poligami. Sementara dari segi historisnya, kitab ini menjelaskan tentang praktek poligami yang terjadi pada beberapa ummat Islam. Menurut kitab ini hukum poligami adalah boleh dengan syarat mampu berlaku adil dan sebaiknya bukan anak yatim piatu. Namun, dalam keadaan tertentu (darurat) poligami bahkan menjadi wajib untuk dilakukan. Menurutnya, kebolehan poligami ini merupakan solusi untuk menghindari perzinaan dan masyarakat bisa terjaga dengan baik.
\end{abstract}

Katakunci : Tafsir al-Ma'rifah; Musthafa Umar; Poligami.

\begin{abstract}
This article discusses polygamy from the perspective of the book of Tafsir al-Ma'rifah by Musthafa Umar by using descriptive analysis methods and the I'jtima'i theory. In this research, the writer found that this Tafsir al-Ma' rifah book discusses polygamy from the aspect of improving society (Islah Ijtima'i). In terms of asbabun nuzul, this book only describes in general the history of the decline in the verse polygamy. While in terms of its history, this book describes the practice of polygamy that occurs in some Muslims. According to this book the law of polygamy is permissible on the condition of being able to be fair and should not be an orphan. However, in certain circumstances (emergency) polygamy even becomes mandatory to do. According to him, the ability of polygamy is a solution to avoid adultery and the community can be maintained properly.
\end{abstract}

Keywords: Tafsir al-Ma'rifah, Musthafa Umar, Polygamy. 


\section{PENDAHULUAN}

Salah satu masalah yang selalu hangat di masyarakat walaupun sudah lama terjadi tapi masih diperbincangkan di kalangan ahli hukum dan mufassir dulu sampai sekarang adalah masalah poligami. Poligami sebagai salah satu bentuk perkawinan bagaikan buah simalakama yang tidak dapat terpisahkan, selalu ada pihak yang tidak setuju dan yang mendukungnya. Kata poligami sendiri selalu bermakna negatif dalam realitas sosial. Mereka yang anti poligami melontarkan berbagai tuduhan yang mendiskreditkan dan mengidentikkan poligami dengan hal-hal yang negatif. Sedangkan bagi kalangan yang pro, mereka melegalkan poligami dan meyakini bahwa poligami adalah perkara yang dituntut agama dan telah dipraktikkan berabad- abad lamanya oleh berbagai bangsa di dunia.

Bahkan di kalangan ulama sendiri terjadi perbedaan pendapat, yaitu antara ulama klasik dengan ulama modern. Ulama kalsik membolehkan poligami sementara ulama modern terutama kalangan feminis mempermasalahkan dan memperberat syarat- syarat yang harus dipenuhi oleh laki-laki yang ingin poligami. Bagi kalangan femenis, poligami dianggap sebagai salah satu bentuk ketidaksetaraan antara laki-laki dan perempuan. Selain itu, poligami juga dianggap sebagai peninggalan zaman jahiliyah, di mana pada waktu itu perempuan diperlakukan sebagai makhluk kelas kedua yang keberadaannya tidak diperhitungkan sehingga mereka bebas memiliki istri berapa saja mereka mau.

Oleh karena permasalahan poligami ini berkaitan erat hubungan sosial masyarakat, menurut penulis akan lebih tepat jika masalah poligami ini dilihat dari perspektif Islah Ijtima'i. Agar masalah poligami tidak selalu dipahami secara setengah-setengah sehingga dipraktikkan secara semena-mena. Sebab, praktik poligami yang terjadi di kalangan masyarakat sama sekali berbeda dari tujuan dibolehkannya poligami oleh al- Qur"an. Kebanyakan praktik poligami yang terjadi hanya karena alasan hawa nafsu (syahwat) semata, bukan lagi karena ingin melindungi dan mengayomi kaum wanita seperti yang dicontohkan oleh Nabi Muhammad SAW.

\section{METODE}

Metode yang diguna pakai dalam penelitian ini adalah metod kajian kualitatif dengan menggunakan metode analisis dokumen, yaitu kajian tentang isi kandungan kitab Tafsir al-Ma'rifah. Kajian ini dibagi menjadi empat metode iaitu, 
metode penentuan subjek, reka bentuk kajian, metode pengumpulan data, dan metode analisis data. Subjek penelitian yang dipilih adalah kitab Tafsir al-Ma'rifah, yang di karang oleh Musthafa Umar. Fokus kajian ini adalah kepada biografi beliau, dan metode beliau dalam mentafsirkan al-Quran terhadap hukum Poligami, dan metode al-Islahi al-Ijtimaci.

Reka bentuk kajian yang dilakukan dalam tesis ini adalah kajian kualitatif yang berbentuk kajian analisis kandungan kitab. Adapun sumber utama dalam kajian ini adalah kitab Tafsir al-Ma'rifah, fokus pada surah An-Nisa' ayat 3. Pertama, metode yang diguna pakai ialah kajian kepustakaan dengan menggunakan pendekatan analisis deskriptif. Kajian ini bertujuan mengumpulkan data-data melalui pembacaan dan penelitian isi kandungan kitab Tafsir al-Ma'rifah serta mengumpulkan data-data yang berhubung kait dengan Musthafa Umar dan kitab Tafsir al-Ma'rifah. Kedua, kajian ini juga menggunakan metode wawancara untuk mendapatkan data-data yang penting dan tepat yang berhubungkait dengan kajian. Kajian wawancara berstruktur dilakukan dengan wawancara pengarang kitab tafsir al-Ma'rifah, iaitu Musthafa Umar. Wawancara dilakukan di kantor beliau di Tafaqquh Study Club Riau, pada tanggal 15 Februari 2014 hingga 19 Februari 2014.

\section{HASIL DAN PEMBAHASAN}

\section{A. Islahi Ijtima'i}

Makna Al-Islahi berasal daripada bahasa Arab yaitu الاصلاحي diambil dari asal kata fi'il Madhinya صلح bermakna memperbaiki, baik, dan bagus. ${ }^{1}$ Ia membawa maksud satu tindakan atau gerakan yang bertujuan untuk merubah masyarakat yang rusak akhlak serta akidahnya, menyebarkan ilmu pengetahuan dan memerangi kejahilan, menjauhi pemikiran dari perbuatan taqlid $^{2}$ dan menjauhi keistimewaan seseorang hanya kerana atas sikap perkauman. ${ }^{3}$ Sedangkan al-Ijtima'i pula berasal daripada bahasa Arab juga iaitu yang bermaksud masyarakat ${ }^{4}$. Dalam bahasa Inggirs diartikan sebagai "society", Ia menggambarkan suatu kehidupan yang dipenuhi pelbagai manusia dan bangsa yang membolehkan mereka hidup bersama dengan penuh

\footnotetext{
${ }^{1}$ Al-Munawwir, Kamus Bahasa Arab al-Munawir digital h. 788

${ }^{2}$ Taqlid adalah mengikuti satu pendapat tanpa mengetahui hujah dan dalil yang kuat

${ }^{3}$ Khairuddin Said, Gerbang Usul Tafsir, (Johor Bahru: Perniagaan Jahabersa, 2013), h. 208-209

4 Al-Munawwir, Kamus Bahasa Arab al-Munawir digital, h. 210
} 
aman-damai, harmoni dan sentosa serta penuh kerukunan ${ }^{5}$. Menurut Khairuddin Said istilah Islah sering beriringan dengan istilah Tajdid. Tajdid adalah suatu usaha pembaharuan untuk menghidupkan kembali ajaran agama yang hilang. Ia berusaha menghilangkan bid'ah dan kurafat yang dapat merusakkan ajaran agama Islam.

Maksud gabungan daripada kata al-Islahi al-Ijtima'i adalah suatu metode yang digunapakai dalam mentafsirkan al-Qur'an berdasarkan kepada kefahaman yang mendalam tentang kandungan ayat-ayat al-Qur'an untuk memperbaiki keadaan umat Islam pada masa ini. Menurut Musthafa Umar mengenai penggabungan dua jenis metode atau lebih ini adalah metode yang baru dalam bidang tafsir, karena untuk mempermudah menjelaskan tafsir yang digunakan oleh seorang mufassir. Biasanya dalam menyebut metode biasanya hanya menyebutkan satu-satu saja, seperti metode al-Ma'thur, al-Ra'yi, alIjtima'I, al-falsafi, al-shufi, al-Ishari, al-Haraki dan lain sebagainya. Namun dalam menyebutkan terhadap suatu tafsir yang telah dihasilkan seperti tafsir Sayyid Kutub fi Zilalil al-Qur'an maka ada yang menyebutkan sebagai tafsir yang memiliki metode al-Adabi al-Ijtima'i (metode sastra budaya dan kemasyarakatan). Penggabungan dua kata atau lebih ini dilakukan kerana corak-corak tafsir itu tidak cukup diterangkan dengan satu sifat sahaja kerana sifat lain juga sangat dominan didalamnya ${ }^{6}$.

Musthafa Umar terpengaruh dengan pemikiran aliran pembaruan dalam bidang tafsir, di antara tokoh mufassir yang terkenal dengan aliran pembaruan ialah Syaikh Muhammad Abduh dan tokoh-tokoh kebangkitan di Mesir seperti Muhammad Mutawalli Syacrawi dan lain sebagainya, sedangkan di Alam Melayu seperti Buya Hamka dan lain sebagainya sehingga beliau dalam tafsirnya lebih menekankan kepada perbaikan masyarakat.

Musthafa Umar menulis Tafsir ini secara bertahap-tahap, sehingga menjadikan kitab al-Ma'rifah ini terkesan sederhana, namun sarat dengan makna. Seperti dalam menafsirkan ayat demi ayat, ia menyesuaikan sesuai dengan urutan Mushaf Utsmani, yaitu yang dikenal dengan metode tahlili, artinya mufassir menjelaskan aspek-aspek yang terdapat pada ayat-ayat yang

\footnotetext{
${ }^{5}$ Kamarudin Salleh, Ezad Azraai Jamsari \& Idris Zakaria, Prosiding Seminar Serantau Seabad BUYA HAMKA, (Selangor: Fakulti Pengajian Islam, Universiti Kebangsaan Malaysia, 2010), h. 197

${ }^{6}$ Musthafa Umar, Metode 'Aqliyyah Ijtima'iyyah: Kajian terhadap Tafsir al-Sya'rawi, (Kuala Lumpur: Universiti Malaya, 2009), h.78-79
} 
telah ditafsirkan dan selanjutnya menerangkan makna-maknanya sesuai dengan keahlian mufassir.

Pengenalan tentang Kitab Tafsir; Kitab tafsir ini adalah tafsir al-Ma'rifah yang bermaksud "Pengetahuan" menurut Musthafa Umar kitab tafsir ini boleh memberikan pengetahuan kepada Masyarakat sesuai dengan maknanya. Beliau menjelaskan bahawa tafsir ini berusaha mengembalikan masyarakat kepada petunjuk al-Qur'an dan Hadis Nabi S.A.W, serta mencintai keduanya.

Merujuk kepada kamus bahasa Melayu perkataan Ma'rifah tidak ada dijumpai, tapi yang ada adalah Makrifat yang bermaksud pengetahuan, seperti dalam Kamus Dewan:

"Makrifat adalah pengetahuan, (dalam ilmu tasawuf) pengetahuan yang tertinggi atau sempurna". ${ }^{7}$

Dalam kamus al-Tullab Arab - Melayu: "al-Ma' rifah adalah masdar dari kata 'arafa - ya'rifu - ma'rifah, jama'nya ma'arif yang bermakna mengenal, kenal". ${ }^{8}$

Dalam kamus al-Asryyi Arab - Indonesia: "al-Ma'rifah adalah 'Ilm, Ittila Idrak yang bermakna Pengetahuan".?

Dalam kamus Bahasa Arab al-Munjid:

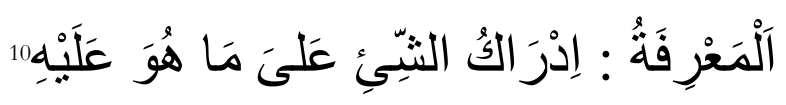

"Perkataan al-Ma'rifah membawa maksud mengetahui suatu perkara dari apa yang telah di pelajarinya".

Dalam kamus Mucjam Maqayis al-Lughah:

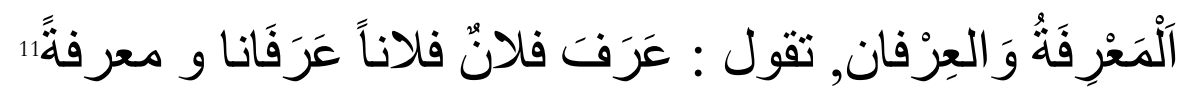

${ }^{7}$ Teuku Iskandar (pnys), Kamus Dewan, (Malaysia: Dewan Bahasa dan Pusaka, Kuala Lumpur, 1984), h.

${ }^{8}$ Al-Ustaz Husein bin Unang, Kamus al-Tullab: Arabi - Melayuwi, (Kuala Lumpur, Dar al-Fikr, 1994), h.

946.

${ }^{9}$ Atabik Ali, Ahmad Zuhdi Muhdlor (pnys), Kamus Karabiak al-cAsriyyi: Arabi- Indonesi, (Yogyakarta, Indonesia: Yayasan Ali Maksum Pondok Pesanteren Krapyak, 1996,) h. 1764.

${ }^{10}$ Luowis Ma'luf al-Yasu'i, Kamus Munjid, Dar al-Kaasunliikiyyah, (Beyrut,1966), h. 500.

${ }^{11}$ Ibn Faris Abu Husain Ahmad bin Faris bin Zakaria, Mucjam Maqayis al-Lughah, Tahqiq, Muhammad 'iwad Mura'ib, Anisah Fatimah Muhammad Aslan. (Beyrut: Dar Ihya al-Turast al-Arabi, 2001), h. 732. 
Maksudnya: Al-Ma'rifah dan al-'Irfan adalah sama maknanya, yang bermaksud, Fulan sangat mengetahui si fulan.

Dalam kamus Mucjam al-Arabi al-Asasi:

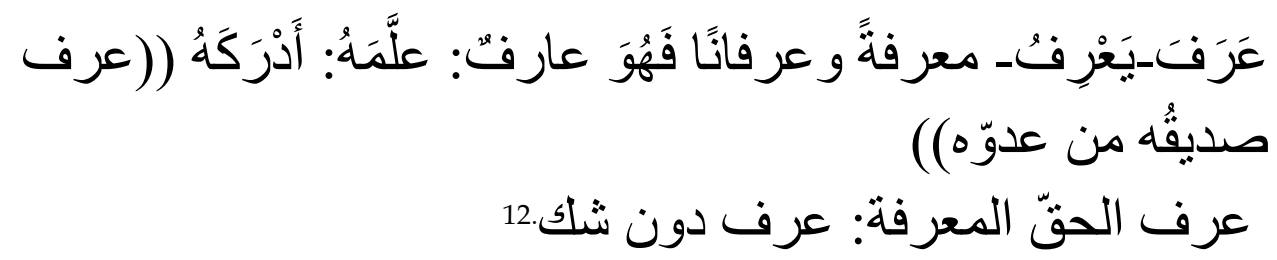

Maksudnya: Perkataan Ma'rifah berasal daripada kata 'Arafa- Ya'rifuMa'rifatan wa 'Irfanan fahuwa 'Arif yang bermaksud mengetahui sesuatu: mengetahui kawannya daripada musuhnya mengetahui kebenaran dengan sebenar-benarnya tahu: mengetahui tanpa ada keraguan.

Uraian di atas memberikan penjelasan bahawa pemilihan nama tafsir beliau dengan al-Macrifah adalah mengisytiharkan bahawa tafsir ini memberikan pengetahuan kepada masyarakat yang tidak faham berbahasa Arab. Untuk memahami makna tafsir al-Qur'an dan memberi semangat baharu untuk belajar dan memahami al-Qur'an. serta mengembalikan segala urusan kepada sumber hukum islam yang utama iaitu al-Qur'an dan Hadis dalam setiap kehidupan seharian.

Pengenalan tentang Pengarang; nama lengkap beliau adalah Musthafa Umar, beliau berasal dari Melayu Riau, beliau tidak memiliki nisbah keturunan. Karena kebanyakan suku di Nusantara tidak memiliki nisbah keturunan. Hal ini berbeda dengan keturunan bangsa Arab yang memiliki nisbah keturunan.

Beliau memperolehi ijazah Sarjana Strata satu di Universitas al-Azhar, kemudian beliau memperoleh ijazah Magister di Universiti Islam Antarabangsa Malaysia dan mendapat gelaran Doktor falsafah (PhD) di Universiti Malaya ${ }^{13}$. Beliau dilahirkan pada 13 Mei 1967 Masehi di Kampung Dalam Senapelan Pekanbaru. Mendapat pendidikan awal di kampung kelahirannya, yaitu sekolah dasar negri di Pekanbaru dan sekolah menengah negri di Pekanbaru. Kemudian melanjutkan pelajaran ke Pondok Pesantren Darussalam Gontor,

\footnotetext{
${ }^{12}$ Ahmad Ayat, Ahmad Mukhtar, Jaelani bin Abi Yahya, Daud Abduh, Soleh Jawwad \& Nadim Mar'asyali, Mucjamal-'Arabi al-Asasi, , (Tunis: Dar al-Durus Jami'ah al-Daul al-Arabiyah:Munazzamah al-cArabiyyah li al-Tarbiyyah wa as-Thaqafah wa al-'Ulum, 1999), h. 834.

${ }^{13}$ Mustaha Umar. Biografi dan Tafsir al-Ma'rifah, Pekanbaru, Riau. Wawancara 15 Februari 2014.
} 
Ponorogo Jawa Timur Indonesia, dan menyelesaikan pendidikan pada tahun $1987 .^{14}$

Pada masa kecil Musthafa telah dididik oleh ibu bapaknya dengan pendidikan agama, waktu pagi hari beliau belajar disekolah rendah, waktu petang pula beliau belajar al-Qur'an dengan Ayah beliau yang juga seorang Guru al-Qur'an. Menurut beliau ayahnya menjadikan rumah sebagai tempat mengaji anak-anak sekolah rendah. Bahkan sampai 40 orang anak yang mengaji di rumah beliau, Sehingga tidak hairan jika beliau sejak kecil sudah memiliki kepandaian dalam membaca al-Qur'an dengan fasih. Bahkan beliau juga diperintahkan oleh ayahnya untuk mengajari kanak-kanak yang sebaya denganya membaca al-Qur'an. ${ }^{15}$

Paradigma berpikir beliau mulai terbuka luas apabila beliau meneruskan pengajiannya dipondok pesantren Darussalam Gontor, Jawa Timur Indonesia, kemudian terus berkembang ketika beliau meneruskan pendidikan di Kairo, Mesir selama empat tahun (1989-1993). Beliau mendapat ijazah Sarjana dari Universitas Al-Azhar, Mesir FakultasUsuluddin jabatan Dakwah pada tahun 1993. Setelah memperolehi Sarjana Muda, Musthafa Umar melanjutkan pelajaran ke peringkat Master di Universiti Islam Antarbangsa Malaysia (19951999) dengan tajuk tesis "Juhud al-Munazzamat al-Islamiyah fii al-Dacwah ila Qabiilati Sakai (Usaha-Usaha Organisasi Islam di Indonesia dalam Berda'wah ke Suku Asli) dan memperoleh ijazah Master di jabatan Dakwah pada tahun 1999. Kemudian memperoleh ijazah Doktor falasah di jabatan al-Qur'an dan Sunnah pada tahun 2009 akademi Pengajian Islam Universiti Malaya Malaysia tahun 2009 dengan tajuk tesis "Metode 'Aqliyyah Ijtima'iyyah: Kajian Terhadap Tafsir Al-Sya'rawi". ${ }^{16}$

Metode tafsir beliau; metode tafsir beliau dapat dibagi menjagi dua metode umum dan metode khusus. Metode tafsir secara umum menceritakan tentang kaidah umum Setiap surah yang akan ditafsirkan, beliau selalu memberikan penjelasan singkat mengenai beberapa perkara yang berkaitan dengan sesuatu surah sebagai pengantar. Perbahasan tersebut meliputi nama Surah dan maknanya (terkadang menyebutkan beberapa nama surah yang berbeda), susunan tafsir berdasarkan urutan tertibnya dalam mushaf menyebutkan tempat turunnya surah sama ada makkiyah (diturunkan di

\footnotetext{
${ }^{14}$ www.musthafaumar.org/sample-page/, diakses pada 15 hari bulan Mac 2014, pukul 14.48

${ }^{15}$ Mustaha Umar.Biografi dan Tafsir al-Ma'rifah, Pekanbaru, Riau. Wawancara 15 Februari . 2014.

${ }^{16}$ Www.musthafaumar.org/sample-page/, diakses pada 15 hari bulan Mac 2014, pukul 14.48
} 
Makkah sebelum hijrah) atau Madaniyah (diturunkan di Madinah setelah hijrah) dan menjelaskan jumlah bilangan ayat, menceritakan secara ringkas isi kandungan surahnya.

Ketika mula masuk dalam perbahasan tafsir, Musthafa menggunakan metode yang sesuai mengikut ayat yang hendak ditafsirkan. Di bawah ini adalah beberapa contoh kaedah am (umum) dalam tafsir surah al-Fatihah dan al-Baqarah:

1. Sebelum mentafsirkan ayat, beliau memberikan tajuk-tajuk tertentu pada setiap ayat dalam surah sesuai dengan susunannya dalam mushaf. Seperti surah al-fatihah, beliau memberikan tema tentang amal. Kemudian pada ayat pertama beliau mentafsirkan tentang ilmu memulakan amal, ayat kedua pula tentang ilmu mengakhiri amal dan seterusnya. ${ }^{17}$

2. Menghubungkaitkan ayat (munasabah ayat) antara ayat yang sedang dibahas dengan ayat sebelum dan selepasnya. seperti surah al-Baqarah. Pada ayat pertama beliau memberikan tajuk orang-orang bertaqwa, kemudian ayat kedua orang-orang kafir, dan ayat ketiga pula tentang orang-orang munafiq. ${ }^{18}$

3. Ayat yang termasuk فواتح السورة (huruf-huruf pembuka surah), Musthafa menyebutnya dengan istilah huruf Muqatta'ah, beliau menjelaskan rahasia makna katanya dalam bahasa Arab dengan pendapat beliau tanpa menyebutkan pendapat para ulama. ${ }^{19}$

4. Musthafa Umar selalu membuat rumusan (istinbat) yang diambil daripada sesuatu ayat yang ditafsirkan yang berkenaan dengan beberapa aspek dalam kehidupan seperti surah al-Fatihah mengandung makna Aqidah, Ibadah, dan Mu'amalah. ${ }^{20}$

5. Menyentuh pembahasan pada aspek fadilah surah-surah tersebut, seperti surah al-fatihah sebagai Ibu atau Induk kitab suci al-Qur'an (Ummul alKitab) dan al-Baqarah sebagai surah yang mesti dibaca bagi setiap muslim, karena membuat Syaitan takut dan juah daripada menghuni rumah itu. ${ }^{21}$

\footnotetext{
${ }^{17}$ Musthafa Umar, Tafsir al-Ma'rifah. (Kuala lumpur:.pt. jil. 1 2000), h. 1-5.

${ }^{18}$ Ibid. h.19-35.

${ }^{19}$ Ibid. h. 20.

${ }^{20}$ Ibid.h. 1-18.

${ }^{21}$ Ibid. h.1 \&19.
} 
6. Menggunakan penggabungan metode Tahlili dan Maudu'i dengan bermatlamat perbaikan masyarakat Islam pada masa ini ('aqliyyah ijtima'iyyah). ${ }^{22}$

7. Menggunakan bahasa melayu yang ringkas, sederhana dan mudah difahami oleh seluruh masyarakat awam.

Metodolologi kandungan kitab Tafsir Al-Ma'rifah (kaedah khusus) Sebagaiamana yang telah dijelaskan di atas, bahwa cara kedua yang dilakukan untuk mencari metodologi kitab tafsir ialah kaedah khusus, yaitu mengkaji isi kandungan kitab tafsirnya secara lebih mendalam supaya dapat menentukan metode tafsir bi al-Ma'thur, metode bi al-Ra'yi, atau gabungan beberapa metode yang lainnya. Ini karena Musthafa tidak menyebutkan metode apa yang digunakan dalam muqaddimahnya. Berikut ini adalah salah satu contoh kajian yang menyeluruh terhadap isi kandungan kitab tafsir al-Ma'rifah.

\section{B. Pembahasan Munasabah Ayat dengan Ayat dalam Satu Surah}

Pembahasan munasabah antara ayat dalam surah al-Qur'an adalah pembahasan satu ayat di suatu tempat tertentu dengan memperhatikan ayatayat lain yang masih berada di dalam surah yang sama. Cara seperti ini ditempuh dalam mentafsirkan ayat kerana kesemua ayat dalam setiap surah alQur'an dipercayai saling menjelaskan antara satu dengan yang lainnya. ${ }^{23}$ Metode ini adalah metode yang digunakan oleh aliran tafsir kontemperor, dalam hal ini Musthafa condong mengikuti cara pentafsiran tafsir al-Sha'rawi. ${ }^{24}$

Musthafa Umar memperhatikan tajuk yang menyatukan sesebuah surah al-Qur'an dan berusaha mentafsirkan ayat-ayat yang ada selepasnya dalam satu surah dengan tidak melepaskan daripada tajuk tersebut didalam tafsir beliau. Seperti beberapa contoh berikut ini:

Ketika beliau mentafsirkan surah al-Fatihah tentang Amal perbuatan Manusia

${ }^{22}$ Menurut Musthafa Umar metode 'aqliyyah ijtima'iyyah adalah metode baharu dalam pentafsiran masa kini, yang bertujuan memperbaiki keadaan umat Islam pada masa ini (rujukan wawancara 19 februari 2014).

${ }^{23}$ Musthafa Umar. Metode 'Aqliyah Ijtima'iyyab: Kajian terbadap tafsir Syaikh al-Shárawi. Tesis Dr. Fal, Universiti Malaya, Kuala Lumpur, 2009), h. 104.

Kaherah Mesir

${ }^{24}$ Hal ini disebabkan beliau mengkaji tentang tafsir al-Sha'rawi dan juga pernah belajar dengan Syaikh di 


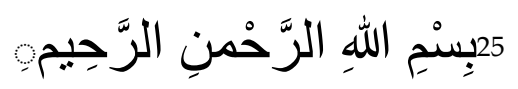

"Dengan Nama Allah Yang Maha Pengasih lagi Maha Penyayang"

Beliau mentafsirkan ayat ini sebagai awal memulakan amal perbuatan hendaklah membaca Bismillah. Kemudian beliau menghubungkan ayat ini dengan ayat selepasnya dalamsurat al-Fatihah juga, yaitu;

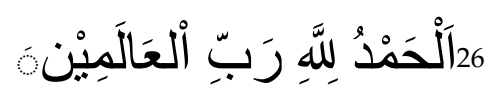

"Segala puji bagi Allah pemelihara semesta alam"

Dalam ayat ini beliau menjelaskan bahawa selepas membaca Bismillah di awal perbuatan, maka cara mengakhiri amal perbuatannya adalah dengan membaca Alhamdulillah. kemudian beliau mentafsirkan ayat selepasnya iaitu setiap amalan akan dibalas oleh Allah SWT nanti di akhirat. Ayat selepasnya pula menerangkan tentang amalan yang diterima dan amalan orang yang ditolak. ${ }^{27}$

\section{Poligami sebagai Perbaikan Masyarakat}

Poligami adalah menikahi perempuan lebih daripada satu orang. Islam memperbolehkan umatnya menikahi perempuan lebih dari satu orang sebagaimana firmanNya:

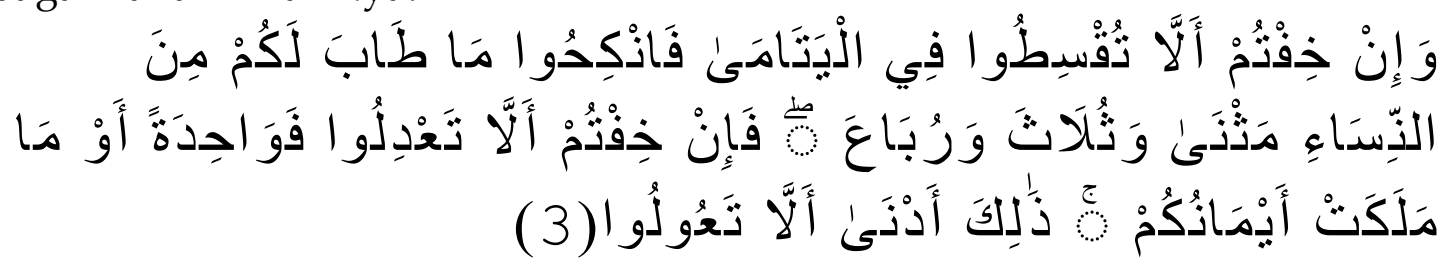

"Dan jika kamu takut tidak berlaku adil terhadap perempuan-perempuan yatim (apabila kamu berkahwin dengan mereka), maka berkahwinlah dengan sesiapa yang kamu berkenan dari perempuan-perempuan (lain): dua, tiga atau empat. kemudian jika kamu bimbang tidak akan berlaku adil (di antara isteri-isteri kamu) maka (berkahwinlah dengan) seorang sahaja, atau (pakailah) hamba-hamba perempuan yang kamu miliki.

\footnotetext{
${ }^{25}$ Al-Qur'an. al-Fatihah 1:1

${ }^{26}$ Ibid., 1:2

${ }^{27}$ Musthafa Umar, Tafsir al-Ma'rifah. (Kuala lumpur: t.pt. jil. 1, 2000), h. 5-10
} 
Yang demikian itu adalah lebih dekat (untuk mencegah) supaya kamu tidak melakukan kezaliman". (Qs. Annisa' ayat 3).

Menurut Musthafa Umar, Islam membolehkan poligami bukan untuk merendahkan kedudukan para perempuan, kerana mustahil Allah menetapkan sesuatu yang buruk dan tercela. Syari'at poligami bukanlah untuk kesenangan hawa nafsu, namun bertujuan untuk hal yang mulia, seperti mendapatkan keturunan jika seorang istri ternyata mandul atau sakit. Kemudian untuk kepentingan dakwah, menjaga kehormatan yaitu takut tergelincir kepada kemaksiatan dan untuk menyelesaikan masalah sosial, sebab jumlah perempuan yang lebih ramai.

Manakala syarat untuk berpoligami dalam ayat ini adalah lebih baik tidak menikahi anak yatim, karena seorang lelaki yang menikahi anak yatim, kebanyakkan ia tidak dapat berlaku adil terhadap anak yatim tersebut. Seorang lelaki dibolehkan menikahi perempuan sebanyak 4 orang, tapi dengan syarat berlaku adil terhadap isterinya, dan jika tidak adil maka Allah menjelaskan dalam ayat tersebut untuk menikahi satu orang saja, karena itu lebih dekat kepada keadilan. ${ }^{28}$

\section{Analisis Musthafa Umar Terhadap poligami}

Usaha Musthafa Umar untuk bersikap adil terkait masalah poligami menurut penulis dapat dilihat dari pendapatnya tentang ketentuan dan syarat poligami yang harus dipenuhi oleh seorang laki-laki. Bahwa laki-laki yang merasa dirinya tidak akan dapat berbuat adil terhadap istri-istrinya, maka tidak dibolehkan melakukan poligami, karena kalau dipaksakan ia hanya akan berbuat aniaya dan lalim terhadap mereka.

Walaupun penafsiran Musthafa Umar terkait masalah poligami ini tidak jauh beda dengan pemikiran ulama-ulama klasik. dimana ia juga membolehkan adanya praktek poligami. Namun, menurut penulis penafsiran yang dilakukan oleh Musthafa Umar lebih menekankan terhadap maslahah perempuan dengan memperberat syarat bolehnya poligami serta memberikan batasan yang jelas tentang jumlah istri yang boleh dinikahi oleh laki-laki dalam satu waktu.

\footnotetext{
${ }^{28}$ Musthafa Umar, Tafsir al-Ma'rifah. Kuala Lumpur: t.pt. jil. 4, pdf. h.1-3
} 
Penulis melihat poligami yang dikehendaki oleh Musthafa Umar berbeda dengan praktek poligami yang terjadi di Masyarakat. Kebanyakan dari mereka yang berpoligami memilih istri kedua, ketiga dan keempat bukan karena ingin melindungi dan mengayomi, tapi lebih kepada hasrat seksual yang dimilikinya, seperti dengan melihat Kecantikan, bentuk tubuh dan kekayaan yang dimiliki wanita tersebut. Oleh sebab itu bagi yang mau poligami, maka seharusnya bisa adil anatara hasrat duniawi dan ukhrowi, iaitu berusaha menyelamatkan kehidupan manusia yang lain, seperti menyelamatkan kemiskinan yang dialami oleh wanita tersebut.

\section{KESIMPULAN}

Menurut Musthafa Umar masalah poligami ini bukanlah hal yang bisa dilakukan oleh semua orang. Sebab poligami yang dibolehkan oleh al-Qur'an hanyalah merupakan dispensasi bagi kaum laki-laki yang merasa mampu untuk berbuat adil pada semua istrinya. Namun, bagi mereka (laki- laki) yang merasa tidak akan dapat berbuata adil di antara istri-istrinya, maka sebaiknya dicukupkan satu saja. Dengan begitu ia akan terjaga dari berbuat dzalim dan aniaya.

Namun dalam saat-saat tertentu, poligami menjadi penting untuk dipraktekan. Sebab kalau ditinjau dari aspek kemanusiaan, laki-laki memiliki hasrat yang lebih tinggi dari wanita, sehingga perlu untuk disalurkan. Maka dari itu, untuk menghindari perbuatan zina al- Qur"ean melegalkan poligami dengan batasan tidak boleh lebih dari empat orang. Pada aspek inilah pendapat Musthafa Umar untuk Islah Ijtima'i.

\section{DAFTAR PUSTAKA}

Al-Qur'an al-Karim

Atabik Ali, Ahmad Zuhdi Muhdlor (pnys). Kamus Karabiak al-cAsriyyi: ArabiIndonesi, (Yogyakarta: Yayasan Ali Maksum Pondok Pesanteren Krapyak, 1996).

Ali Hendri, "Poligami perspektif kitab al-tafsir al-Wasit" dalam al-Bayan Jurnal Studi Al- Qur'an dan Tafsir volume 3 No 1 Juni 2018

Abd Ghofur Mahmud Musthafa Jacfar, al-Tafsir wa al-Mufassiruun. (Kaherah: Dar al-Salam, 2008).

Al-Ustaz Husein bin unang, Kamus al-Tullab: Arabi - Melayuwi. (Kuala Lumpur: Dar al-Fikr, 1994). 
Fauzi Deraman \& Musthafa Abdullah. Pengantar Usul Tafsir, (Shah Alam, Selangor: Akademi Pengajian Islam UM, intel Multimedia and Publication, 2010).

Hamka, Tafsir al-Azhar, (Jakarta: P.T. Pembimbing Masa, 1970).

Ibn Faris Abu Husain Ahmad bin Faris bin Zakaria, Mucjam Maqayis al-Lughah, Tahqiq, Muhammad 'iwad Mura'ib, Anisah Fatimah Muhammad Aslan. (Beyrut: Dar Ihya al-Turast al-Arabi, 2001).

Khairuddin Said. Gerbang Usul Tafsir, (Johor Bahru: Perniagaan Jahabersa, 2013).

Kamarudin Salleh, Ezad Azraai Jamsari \& Idris Zakaria, Prosiding Seminar Serantau Seabad BUYA HAMKA, (Selangor: Fakulti Pengajian Islam, Universiti Kebangsaan Malaysia, 2010).

Luowis Ma'luf al-Yasu'i, Kamus Munjid, (Beyrut: Dar al-Kaasuuliikiyyah, 1966)

Muhammad Mutawalli Al-Sha'rawi, Tafsir al-Sha'rawi, (Kaherah Mesir: Al-Dar Akhbar al-Yaum, Idarah al-Kutub wa al-Maktabat, 1991).

Musthafa Umar, Metode 'Aqliyyah Ijtima'iyyah: Kajian terhadap Tafsir al-Sya'rawi, (Kuala Lumpur: Universiti Malaya, 2009).

---..-. lalai dalam hidup. Diakses pada tarikh tarikh haribulan 25 Januari 2015 pukul 21:23 di blog: http:/ / lamanannur.blogspot.com/2011/01/lalai-dalam-hidup-artikel-olehustaz-dr.html [25 Januari 2015] 30 Perkara penting dalam Hidup. (Pekanbaru : Suska Press, 2009).

----------, Mengenal Allah melalui Sifat dua puluh, (Pekanbaru : Tafaqquh Press, 2005).

Februari, 2013)

2013)

, Kaderisasi ulama sejak dini, solusi atasi krisis ulama, sumber: www. tafaqquhstreaming.com [4 Mei 2014].

Februari, 2014). -, Tafsir al-Ma'rifah. (Kuala Lumpur.t.pt, 2006).

- Metode cAqliyah Ijtimaciyyah: Kajian terhadap tafsir Shaykh Al-Shacrawi.

(Kuala Lumpur: Tesis Dr.Fal, Universiti Malaya, 2009).

-----.-. t.th. Tafsir al-Ma'rifah. Kuala Lumpur

Sayyid Qutb, Tafsir fi Zilalil Qur'an.Terj.Yusoff Zaky Haji Yacob. (Kota Bharu, Kuala Lumpur : Pustaka Aman Press Sdn. Bhd, 2000).

Teuku Iskandar (pnys), Kamus Dewan. (Kuala Lumpur: Dewan Bahasa dan Pusaka, 1984). 